\title{
Anita H. Payne and Matthew P. Hardy, The Leydig Cell in Health and Disease
}

\author{
Humana Press, New Jersey, NJ, 2006
}

\section{Lynn Loriaux}

Published online: 8 December 2007

(C) Humana Press Inc. 2007

This book of 30 chapters and 459 pages provides a comprehensive overview of current research initiatives in Leydig cell biology. The list of authors includes all of the leading investigators in the field. The first chapter, "A History of Leydig Cell Research" by Kent Christensen, is the best available overview of the development of our understanding of Leydig cell biology. This alone is worth the price of the book. Like its predecessor, "The Leydig Cell" published in 1996, the center of gravity of this book is the basic biology of Leydig cell function. And, like its predecessor, this book can be a powerful integrating force in the field and is sure to attract new young investigators to the area. That being said, the second stated purpose of the book, the "Leydig Cell in Disease," is not as well conceived. Finding the clinically relevant material is not easy-it is scattered through chapters with very basic primary content. It would be better if the book had been formatted into two parts-normal and disordered, or some similar structure. That would render the book more user-friendly to the many clinicians trying to access new and clinically "relevant" information about the Leydig cell. Missing are some topics that are common clinical problems; the Leydig cell in Klinefelter's syndrome, the Leydig cell in gynecomastia, the Leydig cell in cirrhosis of the liver, and the Leydig cell in aerobic athletes, among others. Perhaps in the next book. Nevertheless, this book is a most valuable addition to the library of every endocrinologist. It is well written, edited to uniformity, and a treasure trove of valuable reference material.
D. L. Loriaux $(\bowtie)$

Department of Internal Medicine, Oregon Health

and Science University, Portland, OR, USA

e-mail: loriauxl@ohsu.edu 